\title{
Cement Dust Pollution and Morphological Attributes of Groundnut (Arachis hypogaea), Kodinar, Gujrat, India
}

\author{
Sadhana Chaurasia ${ }^{1}$, Ashwani Karwaria ${ }^{2}$ and Anand Dev Gupta ${ }^{3}$ \\ ${ }^{1}$ and $^{3}$ (Dept. of Energy and Environment, MGCGV Chitrakoot Satna M.P., 485 780, India) \\ ${ }^{2}$ (Manager-EHS, Reliance Cement Company Pvt.Ltd, Maihar Satna M.P., 485 772, India)
}

\begin{abstract}
The study aimed to know the effect of cement industry pollutant viz. SPM, RSPM on morphological as well as yield characteristics of groundnut plants grown at different distance from the cement industry at Kodinar, Gujrat, India. The groundnut plant near the industry showed significant deterioration in morphological characteristics. The study indicated that parameters reductions in groundnut correlated directly with particulate pollutant which led to lower yield at more polluted site. Increased concentration of cement dust pollutant causes in visible injuries like progressive decline in photosynthetic ability and closure of leaf stomata and this affect the growth and productivity of the plant.
\end{abstract}

Keywords- Cement industry, Growth parameter, Chlorophyll, Groundnut and yield.

\section{Introduction}

The Study area was Kodinar in the Shaurashtra region of Gujrat state forms a part of a bay in the Arabian Sea. It is located approximately $30 \mathrm{~km}$. from famous temple Somnath (Veraval) on the Veraval-Una National Highway no NH-8E. The area has co-ordinates with latitude, N 20 ${ }^{\circ} 54^{\prime} 45^{\prime \prime}$ and longitude $70^{\circ} 30^{\prime} 41^{\prime \prime}$. In this area there are total 04 cement plant units namely Ambuja Cement, Gajambuja-1, Gajambuja-2 and Siddhi Cement Ltd with capacity 2-2.5 MTPA. It is a most important industrial place.

The pollutants of the cement industry produced the adverse impact on vegetations. Cement industry is the one of the 17 most pollutant industries listed by central pollution control board. In comparison with gaseous air pollutant many of which are readily recognized as being the cause of injury to various type of vegetation. Increase concentration of cement dust pollutant causes invisible injuries like progressive decline in physiological process such as photosynthetic ability and respiration rate of leaves. Similarly visible injury such as reduction in growth and productivity were observed due to cement dust [12].The cement dust decreased the productivity and concentration of chlorophyll in number of crops [7]. Cement dust are potentially harmful to the environment. The direct effects of the cement dust pollution are alkalization of the ecosystem and the changing of the chemical composition of the soil. The pollutant particles can enter the soil as dry, humid or occult deposits and can undermine the physico-chemical property. Hence contaminated soil can adversely affect plant survival and growth [1].

The typical gaseous emissions to air from cement manufacturing plants include nitrogen oxide (NOx), sulphur dioxide $\left(\mathrm{SO}_{2}\right)$, carbon oxide $\left(\mathrm{CO} \& \mathrm{CO}_{2}\right)$ and dust [11], [4]. The dust escaping from cement factories is often transported by wind and deposited in areas close and far away from the factory. These include agricultural lands; natural vegetation, towns and villages, such depositions of particulate matter and other pollutants interfere with normal metabolic activities of plants, causing direct injury and impairment of growth and quality and may ultimately lead to decrease in plant yield.

\subsection{Groundnut}

Groundnut is sown with the onset of monsoon in the area. The black cotton soil makes it suitable to grow groundnuts in the area. Being a cash crop is grown all over the area. However the yield depends mostly on the conditions of monsoon. The yield of this crop has a range of $200 \mathrm{~kg}$ to $800 \mathrm{~kg}$ per acre. The lower yield indicates lack of availability of sweet water and in general saline conditions, which are more pronounced near the coastal areas on the south and bordering Arabian Sea.

\section{Material And Method}

The study area was confined around the cement factory i.e. Ambuja cement. Groundnut plant was selected for field studies. The plant samples were collected from various sampling stations $(0.5,1.0$ and $2.0 \mathrm{~km}$ distance from industry) and were compared with control sites Pransli near Gir forest. At control site the cement dust deposition on the plant was almost negligible. After properly cleaning the plant, root, stem and leaves are separated and average length of root and shoot of plants were measured. Also, average numbers of leaves, branches, flowers, and seeds were counted. The fresh underground and above ground plant parts were dried in 
oven at $80^{\circ} \mathrm{C}$ for $24 \mathrm{hrs}$. and then weighted to estimate the biomass (gm/plant) for 100 days at 20 days intervals. Concentration of chlorophyll was determined using the formula given in [6].

For measuring transpiration rate, a simple photometer was devised following the standard physiological technique. For this purpose, the lower end of $25 \mathrm{ml}$ burette was attached with rubber tubing to a glass tube of $0.5 \mathrm{~cm}$ diameter and $12 \mathrm{~cm}$ length. The test plant was inserted into the open mouth of the glass tube which was then sealed with wax. The set was fixed to a stand and filled with tap water. The exposed water surface in the burette was covered with oil to check evaporation. The airtight set up was kept in sunlight for one hour and the amount of water transpired was recorded to compute the transpiration rate as $\mathrm{ml}$ water transpired/100g fresh plant weight/hour.

\subsection{Morphological characteristics}

\section{Result \& Discussion}

The dust escaping from cement industries is often transported by wind and deposited in areas closed and far away from the factory. These include agricultural lands, natural vegetation, towns, and villages. Such deposition of particulate matter and other pollutants interfere with normal metabolic activities of plants, causing direct injury impairment of growth and quality and may ultimately lead to decrease in plant yield.

In terrestrial plant species, the enormous foliar area acts as a natural sink for pollutants especially the gaseous ones. The harmful effects of air pollution on vegetation have already been well documented. Plant growing in polluted environment often responded and showed significant changes in their morphology [15], [5], [2].

The different morphological parameter values of control and plants at various distances from industry were observed for Arachis hypogaea and the results are given in Table-1.

Table 1: Morphological parameter of Arachis hypogaea at various distances from industry in 2011-12.

\begin{tabular}{|c|c|c|c|c|c|c|c|c|}
\hline \multirow[t]{2}{*}{$\begin{array}{l}\text { S. } \\
\text { No. }\end{array}$} & \multirow[t]{2}{*}{$\begin{array}{l}\text { Morphological } \\
\text { Parameter }\end{array}$} & \multirow{2}{*}{$\begin{array}{l}\text { Distance } \\
\text { from } \\
\text { Industry } \\
(\mathrm{km})\end{array}$} & \multicolumn{5}{|c|}{ Age in Days } & \multirow{2}{*}{ Avg. } \\
\hline & & & 20 & 40 & 60 & 80 & 100 & \\
\hline & \multirow{4}{*}{$\begin{array}{l}\text { Shoot Length } \\
(\mathrm{cm})\end{array}$} & Control & 4.20 & 7.30 & 10.40 & 12.70 & 15.20 & 9.96 \\
\hline & & 0.5 & 2.30 & 3.40 & 6.50 & 8.20 & 9.80 & 6.04 \\
\hline & & 1 & 3.30 & 4.70 & 7.40 & 9.40 & 11.40 & 7.24 \\
\hline & & 2 & 3.50 & 6.30 & 7.70 & 11.30 & 12.60 & 8.28 \\
\hline \multirow[t]{4}{*}{2.} & \multirow[t]{4}{*}{ No. of Branches } & Control & 3.00 & 5.00 & 7.00 & 9.00 & 11.00 & 7.00 \\
\hline & & 0.5 & 2.00 & 2.00 & 3.00 & 5.00 & 7.00 & 4.00 \\
\hline & & 1 & 2.00 & 3.00 & 4.00 & 6.00 & 7.00 & 4.00 \\
\hline & & 2 & 2.00 & 3.00 & 5.00 & 7.00 & 8.00 & 5.00 \\
\hline \multirow[t]{4}{*}{3.} & \multirow[t]{4}{*}{ No. of Leaf } & Control & 10.00 & 23.00 & 34.00 & 36.00 & 38.00 & 28.00 \\
\hline & & 0.5 & 5.00 & 14.00 & 22.00 & 24.00 & 26.00 & 18.00 \\
\hline & & 1 & 7.00 & 17.00 & 27.00 & 28.00 & 31.00 & 22.00 \\
\hline & & 2 & 8.00 & 19.00 & 30.00 & 33.00 & 35.00 & 25.00 \\
\hline \multirow[t]{4}{*}{4.} & \multirow{4}{*}{$\begin{array}{l}\text { Root Length } \\
(\mathrm{cm})\end{array}$} & Control & 4.60 & 6.30 & 8.40 & 10.60 & 14.40 & 8.86 \\
\hline & & 0.5 & 2.80 & 3.20 & 5.60 & 7.40 & 9.50 & 5.70 \\
\hline & & 1 & 3.40 & 4.20 & 6.40 & 8.30 & 10.70 & 6.60 \\
\hline & & 2 & 4.10 & 5.30 & 7.60 & 8.80 & 12.30 & 7.62 \\
\hline \multirow[t]{4}{*}{5.} & \multirow[t]{4}{*}{ No. of Flowers } & Control & - & - & 40.00 & 60.00 & 66.00 & 55.00 \\
\hline & & 0.5 & - & - & 28.00 & 42.00 & 48.00 & 39.00 \\
\hline & & 1 & - & - & 30.00 & 46.00 & 52.00 & 43.00 \\
\hline & & 2 & - & - & 35.00 & 48.00 & 55.00 & 46.00 \\
\hline \multirow[t]{4}{*}{6.} & \multirow[t]{4}{*}{ No. of Pods } & Control & - & - & 47.00 & 68.00 & 72.00 & 62.00 \\
\hline & & 0.5 & - & - & 36.00 & 48.00 & 52.00 & 45.00 \\
\hline & & 1 & - & - & 47.00 & 58.00 & 64.00 & 56.00 \\
\hline & & 2 & - & - & 53.00 & 63.00 & 67.00 & 61.00 \\
\hline \multirow[t]{4}{*}{7.} & \multirow{4}{*}{$\begin{array}{l}\text { Wt. of } 1000 \\
\text { grains (gm) }\end{array}$} & Control & - & - & - & - & 423.20 & 423.20 \\
\hline & & 0.5 & - & - & - & - & 343.40 & 343.40 \\
\hline & & 1 & - & - & - & - & 367.50 & 367.50 \\
\hline & & 2 & - & - & - & - & 402.20 & 402.20 \\
\hline
\end{tabular}

3.1.1 Shoot length- From the Table-1 it is evident that the shoot length was found higher $9.96 \mathrm{~cm}$ in control plant. The plant growing at $0.5 \mathrm{~km}$ distance from industry have lesser growth and as the distance 
increases from the industry the shoot length also increases at $2 \mathrm{~km}$ distance shoot length was found higher than the plants growing at $0.5 \mathrm{~km}$ distance [3].

3.1.2 Numbers of branches- Number of branches have no significant difference in control and polluted site plant. The plants growing at $0.5 \mathrm{~km}$ distance from industry have minimum branches 4 but at $1 \mathrm{~km}$ no increases in branch and number of branches increased 5 at $2.0 \mathrm{~km}$ distance.

3.1.3 Number of leaves- Number of leaves increases as the plant goes old the maximum leaf was founding 100 days of age. At control site the average number of leaf was found 28. The numbers of leaf were significantly low 18, in plants nearest to the industry as the distance from industry increases the number of leaves also increases.

3.1.4 Root length- From the Table- 1 it is evident that the average root length was found higher $8.86 \mathrm{~cm}$ in control plant. The plant growing at $0.5 \mathrm{~km}$ distance from industry have lesser growth $5.70 \mathrm{~cm}$ and as the distance increases from the industry the root length also increases at $2 \mathrm{~km}$ distance root length was found higher $7.62 \mathrm{~cm}$ in average [3].

3.1.5 Number of flowers- Till the age of 40 days no flowers were observed after 40 days maximum (55) numbers of flowers was observed in control plant. The plants growing at $0.5 \mathrm{~km}$ distance were having minimum number of flowers 39. The number of flowers increases as the distance of plant from industry increases.

3.1.6 Number of pods- Maximum number of pods was observed 62 at control site. The plants growing at 0.5 $\mathrm{km}$ distance were having minimum number of flowers 45 Table- 1 .

3.1.7 Weight of grain - 1000 oven dried seeds were weight in physical balance to determine the grain weight maximum weight of 1000 seeds was observed in control plant $423.20 \mathrm{gm}$. The significant reduction in grain weight $(363.40 \mathrm{gm})$ was observed in the plant growing at $0.5 \mathrm{~km}$ distance from the industry [8]. Grain weight also increases (402.20 gm respectively) as the distance increases from industry. Such reduction may occur because of the reduced photosynthetic potential of dusted plant as affected by decrease absorption of light [9]. The reduction in numbers was explained due to failures of pollen grains germination on dust laden stigma and failure of fertilization [3]. Reduction in seed weight under cement dust pollution when compared with control crop the highest yield was recorded in control crop and lowest in the plants nearer to the industry [12]. The reduction of yield may be due to the low rate of transpiration and photosynthesis.

\subsection{Dry bio-mass}

\subsubsection{Dry biomass of Arachis hypogaea root}

In the present study Arachis hypogaea was selected in study area. These pollutants affected the morphology and histological changes of plants. Various parameters of studied at three different sites clearly indicated the deleterious effect of cement industry pollution on plant health, such as root length, shoot length, no. of leaf, weight of seeds, no. of seeds and dry weight of root and shoot. The morphological studies of both polluted and control plants revealed the control site plants were healthier than the industrial site. Table- 2 shows that, Fig-1 the average dry weight of Archis hypogaea root in control site were higher 0.20 gm and the plants growing near the industry having minimum dry weight $0.13 \mathrm{gm}$ the dry weight of root increases as the distance from industry. The reduction in dry biomass of ground nut due to cement dust was reported by [10].

\subsubsection{Dry biomass of Arachis hypogaea shoots}

Dry biomass of shoot of Arachis hypogaea was observed in control and at various distances from industry in various age groups of plants. The data are in given in Table-2. The average dry biomass of shoot in control plant was observed higher $1.73 \mathrm{gm}$. The dry biomass of shoot increases as the age of plant increases and the distance from industry increases. The average dry weight of Archis hypogaea shoots shown in Fig-2.

Table-2: Dry biomass (gm/plant) of Arachis hypogaea (Groundnut) plant in control and industrial area (2011-12).

\begin{tabular}{|c|c|c|c|c|c|c|c|}
\hline \multirow{3}{*}{ Control } & \multicolumn{3}{|c|}{ Dry biomass on root } & \multicolumn{3}{c|}{ Dry biomass on shoot } \\
\cline { 2 - 4 } & $\mathbf{0 . 5} \mathbf{~ k m}$ & $\mathbf{1 . 0} \mathbf{~ k m}$ & $\mathbf{2 . 0} \mathbf{~ k m}$ & & \multicolumn{3}{c|}{ Industrial area } \\
\hline 0.17 & 0.06 & 0.08 & 0.09 & 0.32 & 0.27 & 0.24 & 0.30 \\
\hline 0.18 & 0.10 & 0.12 & 0.15 & 0.52 & 0.36 & 0.33 & 0.38 \\
\hline 0.19 & 0.13 & 0.15 & 0.17 & 0.91 & 0.84 & 0.81 & 0.88 \\
\hline 0.20 & 0.14 & 0.17 & 0.19 & 3.10 & 1.32 & 1.28 & 1.43 \\
\hline 0.25 & 0.21 & 0.21 & 0.24 & 3.80 & 2.72 & 2.67 & 2.87 \\
\hline $\mathbf{0 . 2 0}$ & $\mathbf{0 . 1 3}$ & $\mathbf{0 . 1 5}$ & $\mathbf{0 . 1 7}$ & $\mathbf{1 . 7 3}$ & $\mathbf{1 . 1 0}$ & $\mathbf{1 . 0 7}$ & $\mathbf{1 . 1 7}$ \\
\hline
\end{tabular}



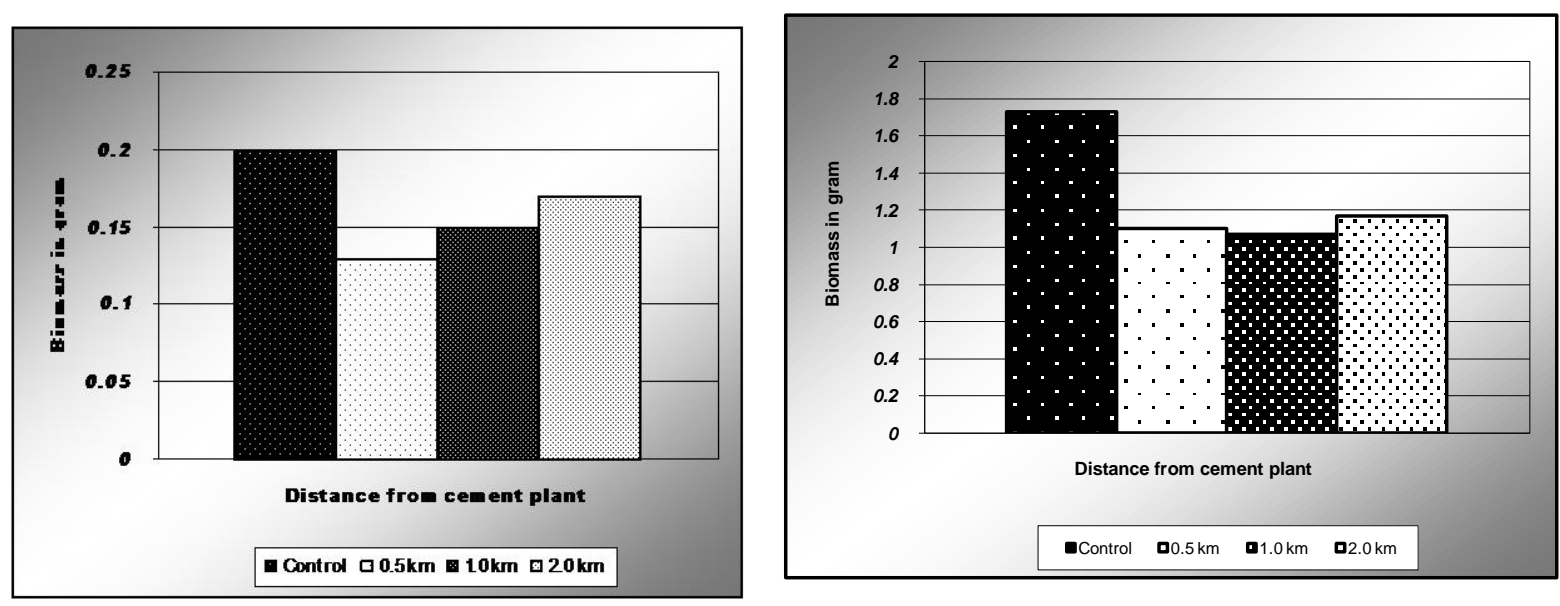

Fig-1: Average dry Biomass of Groundnut root in 2011-12 Fig-2: Average dry Biomass of Groundnut shoots in 2011-12.

\subsection{Transpiration}

Table-3: Transpiration rate (ml. water loss/100 g fresh wt./hour) of Arachis hypogaea (Groundnut) plant in control and industrial area in 2011-12.

\begin{tabular}{|c|c|c|c|c|c|}
\hline S. No. & Plant age & Control & \multicolumn{3}{|c|}{ Distance } \\
\cline { 4 - 6 } & in days & & $\mathbf{0 . 5} \mathbf{~ K m}$ & $\mathbf{1 . 0 0}$ Km & $\mathbf{2 . 0 0} \mathbf{~ K m}$ \\
\hline 1. & 20 & 14.60 & 6.80 & 7.40 & 7.90 \\
\hline 2. & 40 & 15.70 & 8.70 & 9.10 & 9.60 \\
\hline 3. & 60 & 18.70 & 9.20 & 9.60 & 10.20 \\
\hline 4. & 80 & 19.60 & 9.80 & 10.10 & 11.60 \\
\hline 5. & 100 & 20.50 & 10.30 & 10.70 & 11.20 \\
\hline \multicolumn{2}{|c}{ Avg. } & $\mathbf{1 7 . 8 2}$ & $\mathbf{8 . 9 6}$ & $\mathbf{9 . 3 8}$ & $\mathbf{1 0 . 1 0}$ \\
\hline
\end{tabular}

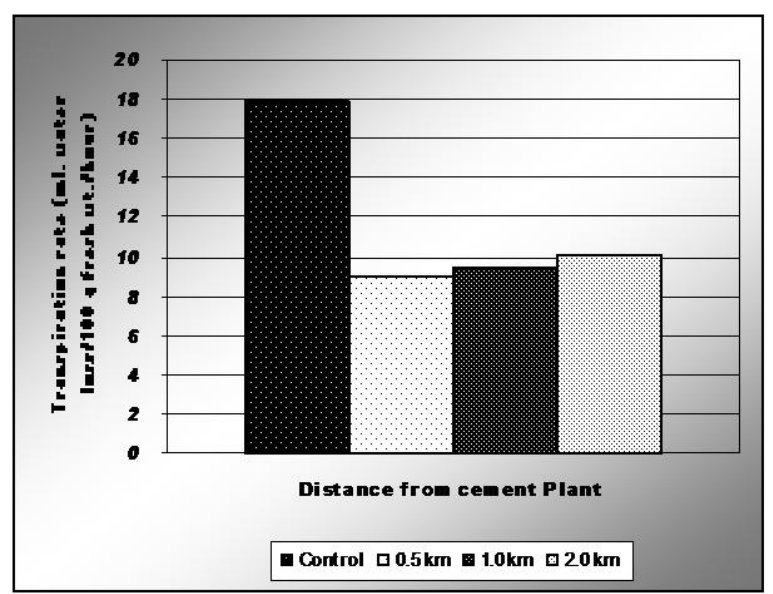

Fig-3: Transpiration rate in Groundnut in 2011-12.

Loss of water through stomata from areal part of plant is known as transpiration. In present study the transpiration rate in Arachis hypogaea plant was observed higher in average $17.64 \mathrm{ml}$ in control plant Table-3, Fig-3. The rate of transpiration increases as the age of plant increases and the distance from industry increases at $0.5 \mathrm{~km}$ distance transpiration rate was observed in average 8.96 which increase 9.38 at $1 \mathrm{~km}$ distance and further increases $10.10 \mathrm{ml}$ at $2 \mathrm{~km}$ distance from industry.

\subsection{Total Chlorophyll}

The total chlorophyll concentration in unit weight of control and plants from various distances from industry was observed for Arachis hypogaea the results are given in Table-4, Fig-4. 
Table-4: Total chlorophyll content of Arachis hypogaea (mg/g drywt. of leaves) in control and industrial area (2011-12).

\begin{tabular}{|c|c|c|c|c|}
\hline \multirow{2}{*}{$\begin{array}{c}\text { Plant age in } \\
\text { days }\end{array}$} & & \multicolumn{3}{|c|}{ Distance } \\
\cline { 3 - 5 } & Control & $\mathbf{0 . 5} \mathbf{~ K m}$ & $\mathbf{1 . 0 0} \mathbf{~ K m}$ & $\mathbf{2 . 0 0} \mathbf{~ K m}$ \\
\hline 20 & 2.44 & 1.65 & 1.86 & 1.94 \\
\hline 40 & 3.20 & 2.46 & 2.72 & 2.70 \\
\hline 60 & 3.95 & 2.53 & 2.60 & 2.78 \\
\hline 80 & 4.35 & 2.50 & 2.55 & 3.10 \\
\hline 100 & 3.92 & 2.10 & 2.20 & 2.32 \\
\hline Avg. & $\mathbf{3 . 5 7}$ & $\mathbf{2 . 2 5}$ & $\mathbf{2 . 3 9}$ & $\mathbf{2 . 5 7}$ \\
\hline
\end{tabular}

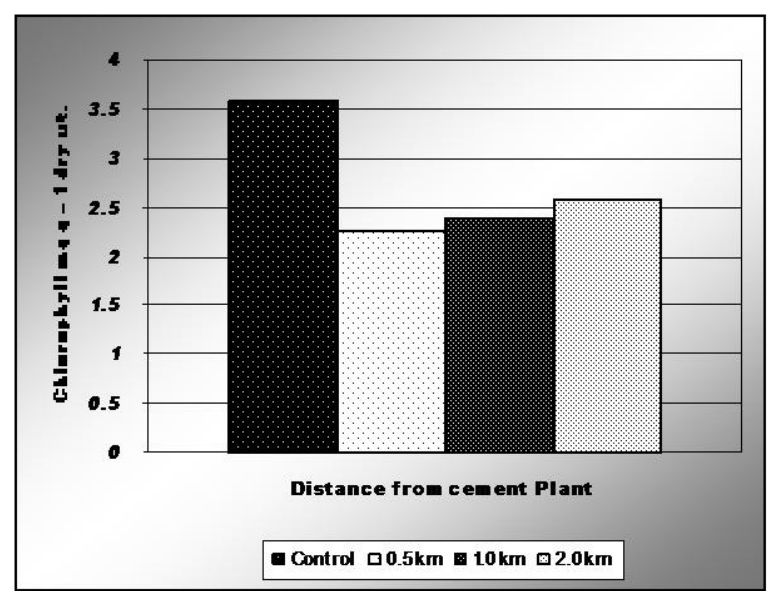

Fig-4: Chloropyll in Groundnut leaves in 2011-12.

Changes associated with chlorophyll content in a cement polluted environment, were associated with a decrease in the levels of stomatal and cuticular transpiration of encrusted leaf surfaces. Destruction was observed in foliar necrosis in coal-dust effect on mango and lemon plants[14]. However, on cement dusted leaves chlorophyll content was always lower at all distance with respect to control plant.

The maximum chlorophyll average concentration was observed in control plant $3.57 \mathrm{mg} / \mathrm{gm}$ dry weight Table-4. The chlorophyll concentration increases as the age of plant increases and the distance from industry increases. At $0.5 \mathrm{~km}$ distance chlorophyll average concentration was observed $2.25 \mathrm{mg} / \mathrm{gm}$. which increase 2.39 at $1 \mathrm{~km}$ distance and further increases 2.57 at $2 \mathrm{~km}$ distance from industry. Chlorophyll concentration increases as the distance from industry increases [13].

\section{Conclusion}

Morphological characters of Arachis hypogaea was studied at different distance from the industry and compared with the control plant. The data obtained at different stage of development indicate that shoot length, root length, number of branches, number of leaves, number of flower, number of seed and weight of seeds were affected by cement industry pollution. The plant growing in control site were healthy than the plant growing near the cement industry. As the distance from the industry increases the plant also improves in all the three selected plant species. The yield in term of seed weight regarding unpolluted plant may be attributed to the photosynthetic potential as against the dusted plant and assimilate supplies to support reproductive development and seed growth. Yield reduction was observed along the gradient of air pollution. A loss in total chlorophyll in the leaves of plants exposed in severe air pollution supports the argument that the chloroplast is the primary site of attack by air pollutants and decreases pigment content in the cells of polluted leaves. The transpiration rate, dry weight, chlorophyll content also shows the similar pattern.

\section{Journal Papers:}

\section{References}

[1] M.A. Addo, E.O. Darko, C.Gordon and B.J.B. Nyarko, Contamination of soils and loss of productivity of Cowpea (Vigna unguiculata L.) caused by cement dust pollution, Inter. J. Res. In Chem. and Env, 3(1), 2013, 272-282.

[2] M. Agrawal, B. Singh, M. Rajput, F. Marshall and J.N.B. Bell, Effect of air pollution on periurban agriculture: a case study, Environmental Pollution, 126, 2003, 323-329.

[3] A. Chauhan and P.C. Joshi, Effect of ambient air pollutants on wheat and mustard crops growing in the vicinity of urban and industrial areas, New York science J, 3(2), 2010, 52-60. 
[4] M. Kampa and E. Castanas, Human health effect of air pollution, Environmental Pollution 151, 2008 362-367.

[5] T. Keller and H. Schwanger, Air pollution and ascorbic acid, European Journal of Forest pathology, 7, 1977, 338-350.

[6] S. Machlachlan and S. Zalik, Plastid structure, chlorophyll concentration and free amino-acid composition of a chlorophyll mutant of Barley, Can J. Bot, 40, 1963, 1053-1062.

[7] D.D. Pandey and S. Kumar S, Impact of cement dust pollution on biomass, chlorophyll, nutrients and grain characteristics of wheat, Environ Ecol 14, 1996, 872-875.

[8] S. Parthasarathy, M. Arunachalam, K. Natarajan, G. Oblisami and G. Rangaswami, Effect of cement dust pollution on certain physical parameter of maize crop and soils, Indian J. Environ. Hlth, 17, 1975, 114-120.

[9] G.J. Peirce, An effect of cement dust on orange trees, Plant World 13, 1910, 283-288.

[10] M.S.V. Prasad and J.A. Inamdar, Effect of cement kiln dust pollution on ground nut, Indian Bot Cont. 7(4), $1990,159-162$.

[11] T. Pregger and R. Friedrich, Effective pollution emission heights for atmospheric transport modeling based on real-world information, Environmental pollution, 157, 2009, 552-560.

[12] D. Raajasubramanian, P. Sundaramoorthy, L. Baskaran, G.K. Sankar, Al. A. Chidambaram and M. Jeganathan, Cement dust pollution on growth and yield attributes of groundnut (Arachis hypogaea L.), International Multi. Res. J. 1 (1), 2011, 31-36.

[13] A.M. Rehman and M.I. Mohamed, Effect of cement dust deposition on physiological behaviors of some halophytes in the salt marshes of red sea, Acad. J. Biolog. Sci, 3(1), 2012, 1-11.

[14] N. Singh and D.N. Rao, Certain responses of wheat plants to cement dust pollution, Environ. Poll. (Ser. A.) 24, 1981, 75-81.

\section{Books:}

[15] P.K. Gupta, Soil Plant Water and Fertilizer Analysis, Agrobios (India), (Jodhpur, 342002, ISBN- 81-7754-038-6, 1999). 